
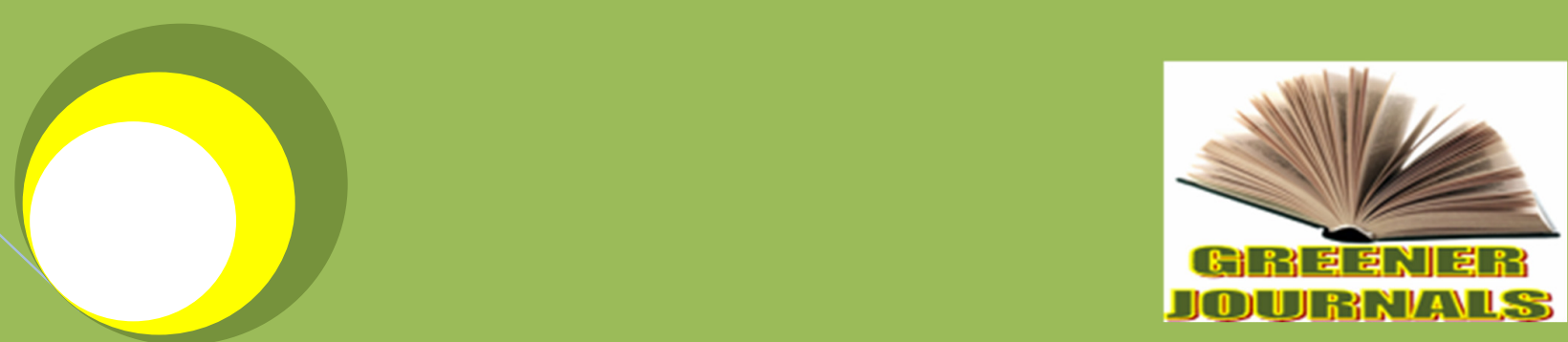

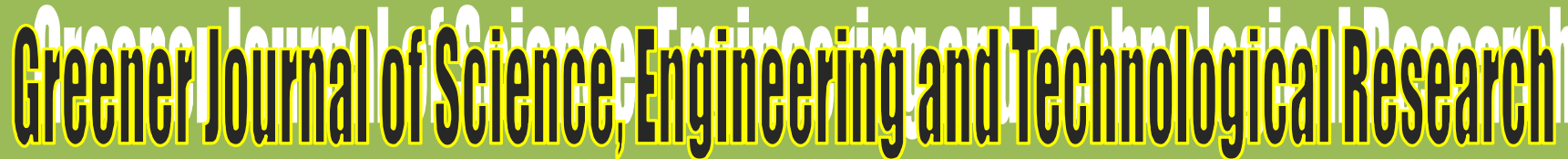

ISSN: 2276-7835 ICV: $\mathbf{5 . 6 2}$

Submitted: $24 / 05 / 2016$

Accepted: 02/06/2016

Published: 21/11/2016

DOI: http://doi.org/10.15580/GJSETR.2016.3.052416098

Mitigating the use of Electric Generators: An Operative Model of Distance and Greening Buffers

By

Akindele O. Akin Adejumobi DO 
Research Article (DOI: http://doi.org/10.15580/GJSETR.2016.3.052416098)

\title{
Mitigating the use of Electric Generators: An Operative Model of Distance and Greening Buffers
}

\section{${ }^{*}$ Akindele O. Akin and Adejumobi DO}

\author{
Department of Urban and Regional Planning, LadokeAkintola University of Technology, Ogbomoso, Oyo State, \\ Nigeria.
}

${ }^{*}$ Corresponding Author Emails: oaakindele37 @lautech. edu.ng; Phone: +234 8038093456

\begin{abstract}
Against the background of the incessant electric power failure and the extensive use of electric power generator, the study investigates the use of electric power generators; so as to proffer ecologically sustainable mitigation strategies. The relative incidence of generator use was appraised. Residents coping mechanism as well as its efficacy were also assessed. Across the three recognizable residential densities of the city having 20 political wards, 50 urban blocks (10\%) were sampled. A questionnaire was administered to 511 respondents using a multi stage approach. Noise dosimeter was used to measure the noise level. Air samplers were also used to assess the magnitude of air pollution across the sampled units. $X^{2}$, T-test and one-way ANOVA were used to explain the variation in the incidence of generator use and to compare the average concentration of pollution with the WHO tolerable standards. A high level incidence of power outage (81\%) was observed to have encouraged a high incidence (78.6\%) of electric generator use with $\mathrm{X}^{2}$, T-test showing a significant difference in the noise levels comparing distance intervals to the generator at $\alpha=.05$. Distance was observed to abate noise and air quality was better with greens at $\mathbf{1 . 9 1 6}$. The study thus recommends a distance and green buffer to mitigate the negative effects of electric power generator use.
\end{abstract}

Keywords: Electric power generator, basic utility, carbon capture, pollution, livability, Nigeria.

\section{INTRODUCTION}

Electric power in Nigeria has a long history of inefficiency and unreliability. More than $70 \%$ Nigerians do not have access to good electricity (Oyedepo, 2012).Almost every household are therefore forced to live with carbon monoxide through the use of electric power generator. The overall productivity of businesses has been hampered by the incessant electric power failure. Pupils and households, even hospitals still use open flame lanterns to lighten their homes and workplaces to read, do assignments and attend to issues. Frustrations, boredom and other difficulties have discouraged learning, making the children very lazy at studies. Volatile and flammable hydrocarbons are stored in unspeakable places which have often times resulted in terrible fire accidents that brought loss of lives and properties. No wonder that, frequently, there are mass casualty reports in the Nigerian mass media on carbon monoxide poisoning from electrical power generators (Ajiboye et al, 2014).

The number of electric generator used by individuals in Nigeria probably equals the number of activities he does. Home, workplace, place of worship and social gatherings among others depend on electric generator. Some artisans move about with portable electric power generators to enable them undertake their daily jobs. All of these point to a high level usage of electric power generators. The amount of fossils fuel burnt and the resulting environmental pollutant produced daily is therefore only better imagined.Electric power generators necessarily combust hydrocarbon fuel in its operation. This combustion may be complete but most of the time; incomplete. This process produces harmful gaseous pollutants, and is capable of killing the unsuspecting users gradually. Carbon monoxide, $\mathrm{CO}$, carbon dioxide, $\mathrm{CO}_{2}$, and the hydrocarbons are the "greenhouse gases," believed to be responsible for global warming. $\mathrm{SO}_{x}$ and $\mathrm{NO} \times$ produce acid when released into the atmosphere, leading to the production of acid rain. (Lopez, 2007).However, public electricity today has been relegated to the background for the popularization of generator use. Electric power generators contribute in very high measure to environmental noise that remains harmful to residents' health (Westmam and Walters, 1981; Pichot, 1992; Stansfeldet al, 2000; passchieret al, 2000).

With the trend of generator use, a decarbonized future is an illusion. The pathology of global warming, loss of biological diversity, inequality, ecological injustice and poverty are inextricably connected. All of them centre on the urban context; where the fluoro-chloro-carbon compounds are generated in volume that exceeds the carrying capacity of the local environment (UN-HABITAT 2011). With the view to proffer pragmatic and sustainable solutions, this complex problem must be approached from diverse directions as it also has implications in multiple connections with physical, social, economic and scientific dimensions. To this end, the visible and ingrained problem of alternative power and energy use which has found expression in the use of 
electric generators cries for attention. The scientific approach to what, where and how to intervene positively ranging from macro to micro social dynamics need to include utility provision that is cognizant of sustainable environment, this is supposed to regard environmental history, social economic behavior, social movement as well as bio-technological innovations. All these and much more comprise the human dimensions that are implicated in understanding the hindrances to sustainable environment; part of which this study addresses.

Carbon monoxide is the major product of combustion arising from the use of electric generator. It is the commonest cause of accidental poisoning (Guy et al, 1999). It was noted to be poisonous and dangerous as a result of its reversible displacement of oxygen from haemoglobin to form carboxyhaemoglobin (Blumenthal, 2001).Poisoning may still result even with passive ventilation (McDonald et al, 2010) this suggests that the multiple use of electric generators in high density areas is one of the greatest risks to human livability in cities. Britain records an average of 50 deaths and 200 severe morbidity cases annually (Guy et al, 1999). Annual death rate as a result of carbon monoxide poisoning in America was put at 1.5 per million persons. This vulnerability increases with increase in age of the victims. For instance, fatality of carbon monoxide poisoning was highest in Americans aged 65 years and older (Gasman et al, 1990). This means more doom especially to traditional cities in Nigeria; where more elderly people live in the high density areas and where there is high concentration of small electric power generators that are known for incomplete combustion.

When electricity is a sine-qua-non to urban living but is not readily available from a sustainable environmental friendly means, but the usage of electric power generators; what happens to the local and the global environment? How should urban residents cope in the short and long term? What cheap stress - free and sustainable methods may be proffered to at least alleviate the problems which may be emanating from the usage of electric power generators? While the Government battles with the efficient provision of sustainable and environmental-friendly electricity, it is imperative to know what may be done to prevent the adverse effects of electric generator usage. There is need to investigate the means to cushion the effects of electric generator use. To this end, the study investigates how to mitigate the environmental problems that stems from the use of electric power generators.

\section{Concept of Distance Decay and First Law of Geography}

This first law of geography and distance is worded by Waldor Tobler (1930) as "Everything is related to everything else, but near things are more related than distant things." Not all space is equal so distance decay is not equal. Roads, mountains, water ways, and many more natural and manmade obstacles slow and speed up distance decay. Other things can compete for space against the decaying phenomena and become stuck or even reversed. Distance decay is a geographical term which describes the effect of distance on cultural or spatial interactions. (Fellman, Getis, and Getis. 2010). The distance decay effect states that the interaction between two locales declines as the distance between them increases. Once the distance is outside of the two locales' activity space, their interactions begin to decrease.

This concept is applicable to the research topic because of the strong correlation between distance and noise produced by the generator. When a generator is given adequate setback, the sound intensity it will emit will be tolerable to human ear and will have no adverse effect on the ear (Paschier et al, 2000; Stansfeld et al, 2000). Reverse is the case if the generator is not given adequate setback and the intensity of sound will have a lot of harmful health effect on people around due to frequent exposure to such noise (Pichot, 1992). According to the American Speech- Language hearing association, these effects include elevated blood pressure, negative cardiovascular effects, increased breathing rates, indigestion, and stomach disturbances; ulcers, negative effects on developing fetus, difficulty in sleeping even after the noise stops, and increased fatigue.

In addition, according to the distance decay law (Tobler, 1930), natural and man-made obstacles also slow and speed up distance decay. What this implies to the study is that the presence of obstacles in form of wall (man-made), vegetation (natural) can reduce the intensity of noise on human health and even reduce the environment effect of generator in the study area. The man-made wall will serve as an obstacle and reduce the intensity of noise. The importance of plants in sustainability of environment cannot be overestimated because the carbon pollutants evolved by generators are being absorbed by the process of photosynthesis in plants.

\section{METHODOLOGY}

Primary and secondary data were used. Out of the total (561), 50 (10\%) urban blocks were sampled across the three recognizable residential densities in the 20 political wards of the town. Using a multi stage approach, a questionnaire was administered to 511 respondents eliciting information on electric generator usage, residents coping strategies and their effectiveness among others. Tabulations, cross-tabulation and percentages constitute the descriptive statistics that presents the findings and summarize the data. Likert scaling was used to scale ordinal data, making them amenable to parametric testing. The noise dosimeter is used to calculate the noise level-distance graph and this facilitates the estimation of minimum distance buffer from the generator to put the residents within a tolerable noise level zone. Air samplers were also used to assess the magnitude of air pollution 
across the sampled units.Chi-square, One sample t-test and one-way ANOVA were used to explain the difference in the standard air quality and the mean/average air quality in the different areas sampled.

\section{DISCUSSION OF FINDINGS}

This section discusses the data gathered, analyzed and interpreted. It essentially discusses the incidence of generator use, residents' livability and the relationships between the two. During the discussion, the town planning implications are highlighted. The interpretation is tailored to how much risks are undertaken by residents through the use of electric generator and how residents may cope or be resilient with the continued use of electric generator since they may still have to continue to use the generator in the meantime. The section begins with the assessment of generator use. This is followed by the measurement of residents' livability against the background of the usage of electric generator. Here, acute and imminent effects of generator use are factored into the interpretation. This suggests to us what the usage of electric generator can do to our individual lives, city and the globe.

\section{Incidence of Generator Use}

Understanding the incidence of generator use is not very simple. Number of persons having a generator alone would not give the best picture if the incidence of power outage is not investigated. Incidence of power outage alone would not tell in precise terms the number of hours that each individual or individual household put their electric generators on. The number of the working hour of the sampled generator may not also tell us the amount of fuel burnt per day and so the actual estimation of the pollutants produced by the generator. This is because, the age of generator, frequency of servicing the generators, type of generator in terms of capacity and the type of fuel it uses need to be factored into the conclusion.

The incidence of power outage was estimated from the number of hours during which the residents could not enjoy electricity from the government, per day, the number of days in a week and the rate at which it trips off. The number of generator work hour, average volume of fuel used per day, number of generators in the building, age of generator, distance to building, number of generator used for domestic or other uses were measured in interval scale. It must be stated here that for the purpose of analysis, the scaling used for all the ordinal data here allotted more weight to the negative values of generator use. For instance, the respondents rating of the incidence of power outage starts from 'very much significant', 'very significant', 'just significant', and 'not significant 'to' not at all significant. The weights allotted to these respectively are $0,1,2,3$ and 4 . So that when power outage is not significant at all, it will score a higher point. This will align the scaling with the purpose of analysis and computation combination with other variables may be meaningful.

The incidence of power outage is very high and it spares no area of the town. The rate of power outage is only relatively different if areas are compared. The rate is not different significantly when compared statistically (the probability value of the $X^{2}$ is .124). Areas that fall within Ogbomoso North seem to rate their power outage lower compared to their counterparts from the South. This probably is connected to the presence of high class end users in the northern local government who probably receive more attention from the service providers because of their ability to pay. For this reason, almost everyone (78.6\%) has one electric generator at least! Very many residents have more than one generator especially in the high density area. There are more electric generators in the high density area where there are more independent households in a building who would need electricity but can only afford a small one capable of satisfying only their family units. Many residents in the area are artisans and would need at least a small sized electric generator to do their petty business. This explains why the incidence of generator use increases with increase in land use mix; each land use activity would require the use of an electric generator which is independent of the ones used domestically by households.

On the average, most of the residents have used three generators in their houses. This suggests that electric generator usage is an age long practice in homes. It also suggests that electricity is not a luxury; its need is super basic to livability. The failure of the government to fix the basic needs of the city in terms of public utilities and services, have forced residents to the use of electric generator. The resource drain and environmental pollution has been promoted by the absence of sustainable electric power generation in the country. The age of generator currently in use was obtained in months. When this is added to the number of electric generated ever used, the damage done to houses, individuals, households as well as the local and global environment is only better imagined. 
Table 1: Incidence of Generator Use.

\begin{tabular}{|c|c|c|c|c|c|c|c|c|c|c|c|c|c|c|c|c|c|c|c|c|c|}
\hline Variable & 1 & 2 & 3 & 4 & 5 & 6 & 7 & 8 & 9 & 10 & 11 & 12 & 13 & 14 & 15 & 16 & 17 & 18 & 19 & 20 & $\mathrm{X}^{2}$ \\
\hline $\begin{array}{l}\text { Power } \\
\text { Outage }\end{array}$ & 48 & 37 & 38 & 38 & 40 & 39 & 33 & 45 & 45 & 44 & 43 & 44 & 45 & 41 & 40 & 45 & 45 & 43 & 46 & 44 & .124 \\
\hline $\begin{array}{l}\text { Gen } \\
\text { Possession }\end{array}$ & 78 & 62 & 71 & 74 & 84 & 72 & 71 & 96 & 81 & 81 & 92 & 77 & 64 & 72 & 83 & 81 & 86 & 87 & 71 & 89 & .305 \\
\hline $\begin{array}{l}\text { Use } \\
\text { Regularity }\end{array}$ & 51 & 54 & 48 & 45 & 52 & 57 & 54 & 49 & 48 & 45 & 44 & 52 & 51 & 56 & 55 & 49 & 48 & 52 & 53 & 50 & .061 \\
\hline $\begin{array}{l}\text { Work } \\
\text { Hour/day }\end{array}$ & 9 & 10 & 6 & 6 & 7 & 10 & 9 & 9 & 8 & 9 & 8 & 5 & 6 & 7 & 9 & 9 & 8 & 8 & 7 & 10 & .052 \\
\hline $\begin{array}{l}\text { Fuel } \\
\text { used/day }\end{array}$ & 5 & 3 & 2 & 7 & 4 & 5 & 6 & 5 & 5 & 4 & 10 & 5 & 5 & 4 & 8 & 6 & 7 & 9 & 5 & 6 & .051 \\
\hline $\begin{array}{l}\text { No in } \\
\text { Building }\end{array}$ & 1.7 & 1.4 & 1.8 & 1.4 & 1.6 & 1.4 & 1.3 & 1.1 & 1.1 & 1.2 & 1.6 & 1.2 & 1.6 & 1,3 & 1,4 & 1.4 & 1.6 & 1.3 & 1.4 & 1.1 & .045 \\
\hline $\begin{array}{l}\text { No of Gen } \\
\text { Used }\end{array}$ & 3 & 2 & 4 & 4 & 3 & 4 & 3 & 4 & 4 & 3 & 2 & 3 & 3 & 5 & 5 & 3 & 3 & 4 & 4 & 3 & .068 \\
\hline $\begin{array}{l}\text { Age } \\
\text { (Month) }\end{array}$ & 32 & 39 & 38 & 41 & 40 & 35 & 34 & 35 & 27 & 33 & 31 & 37 & 33 & 34 & 36 & 34 & 37 & 33 & 34 & 36 & .002 \\
\hline $\begin{array}{l}\text { Service } \\
\text { Regularity }\end{array}$ & 2 & 3 & 1 & 3 & 2 & 3 & 1 & 5 & 2 & 3 & 4 & 3 & 2 & 2 & 2 & 4 & 3 & 2 & 2 & 5 & .051 \\
\hline Fuel type & 2 & 2 & 2 & 2 & 2 & 2 & 2 & 2 & 2 & 2 & 2 & 2 & 2 & 2 & 2 & 2 & 2 & 2 & 2 & 2 & .443 \\
\hline $\begin{array}{l}\text { Distance to } \\
\text { Building }\end{array}$ & 0.8 & 0.5 & 0.8 & 0.9 & 0.7 & 0.8 & 0.7 & 2.5 & 0.9 & 0.6 & 0.5 & 0.7 & 0.8 & 0.6 & 0.9 & 0.8 & 0.5 & 0.6 & 0.9 & 1.7 & .453 \\
\hline $\begin{array}{l}\text { Domestic } \\
\text { use }\end{array}$ & 61 & 68 & 66 & 69 & 67 & 79 & 77 & 92 & 81 & 73 & 71 & 69 & 65 & 69 & 69 & 76 & 78 & 67 & 68 & 89 & .133 \\
\hline Other use & 39 & 32 & 34 & 31 & 33 & 21 & 23 & 8 & 19 & 27 & 29 & 31 & 35 & 31 & 31 & 24 & 22 & 33 & 32 & 11 & .112 \\
\hline Mean & 26 & 24.1 & 24 & 24.8 & 25.9 & 25.3 & 24.2 & 27.2 & 24.9 & 25.1 & 26 & 25.4 & 24.1 & 25 & 26.3 & 25.8 & 26.2 & 26.3 & 25.1 & 26.8 & .114 \\
\hline
\end{tabular}

Source: Author's Field Survey, 2014

Akata-1, Alafia oluwa-2, Arowomole-3, Caretaker-4, Idioro-5, ljeru-6, ljeru2-7, Low cost-8, Odokoto-9, Oke alapata-10.

Adenike-11, Aaje-12, isale afon-13, agboyin-14, adiatu-15, high court-16, okelerin-17, sabo-18, isaleora-19, papa alajiki-20

Electric generator usage was found to be regular as most of the areas scored low points in the rating. This must be due to the regularity of power outage. On the average, residents use their electric generators for 8 hours daily and regularly. These generators mostly use gasoline; that is why they score very low on fuel type. Residents in high density areas used the small 'Tiger' brand of electric generator (I better pass my neighbor) in which the engine oil is mixed with gasoline for all the working time. This, combined with the age of the generators as well as the general poor attitude toward its maintenance would produce incomplete combustion that produces even more dangerous pollutants in the environment.

Because of the size of the generators, ignorance of the carbon monoxide poisoning and the unwillingness of the users to spend more for wiring, generators were observed to be located at proximal distance to the buildings. The average distance between generators and buildings for most areas sampled is less than a meter except for low cost area and papa Alajiki. While some create some distance very many do not. When these are summed together, the mean average put the average distance between generator and buildings at a figure less than a meter. Very many residents especially in the high density areas would plug the wire coming from their small generators directly into an electrical socket in the building. Many of these residents are tenants who do not want to install anything permanent in their rented apartments. This gives no room for the generator to be housed securely at a reasonable distance and to forestall the direct inhalation of poisonous fumes. It also brings the loud noise closer to residents, exposing them to all the risks associated with the use of electric generators. There are so many implications on the use of electric generators. The environmental implications would be better appreciated if parameters mentioned above are all factored into the incidence of usage of these electric generators. The general discomfort leading to environmental health issues combined with social cum economic problems can never be over-emphasized.

One sample t-test was used to compare the WHO stipulated standard for the tolerable outdoor noise level and the mean averages of the ambient noise levels obtainable from the areas sampled. It was observed that there is a significant difference at $95 \%$ confidence level (the probability value is .000 ). Only two of the twenty areas sampled $(10 \%)$ has ambient noise level that stays within the healthy range. The rest has some 3 decibels more on the average. The mean average of ambient noise intensity for the study is $58.2 \mathrm{db}$. This is above the WHO standard for outdoor tolerable noise level. There can be a lot of social and health and environmental implications for this persistent high noise intensity (Stansfeldet al, 2000;Pichot, 1992 ; Westman and Walters, 
1981). It may increase annoyance thereby increasing the rate at which residents develop nervous health problems (Donney, 2011). The age bracket of victims of hypertension is ranging downward from 60 years to 40years and even less (Afolayan et al, 2014). More people present with migraine and insomnia among others which are related to environmental stress among which usage of electric generator is a strong contributor.

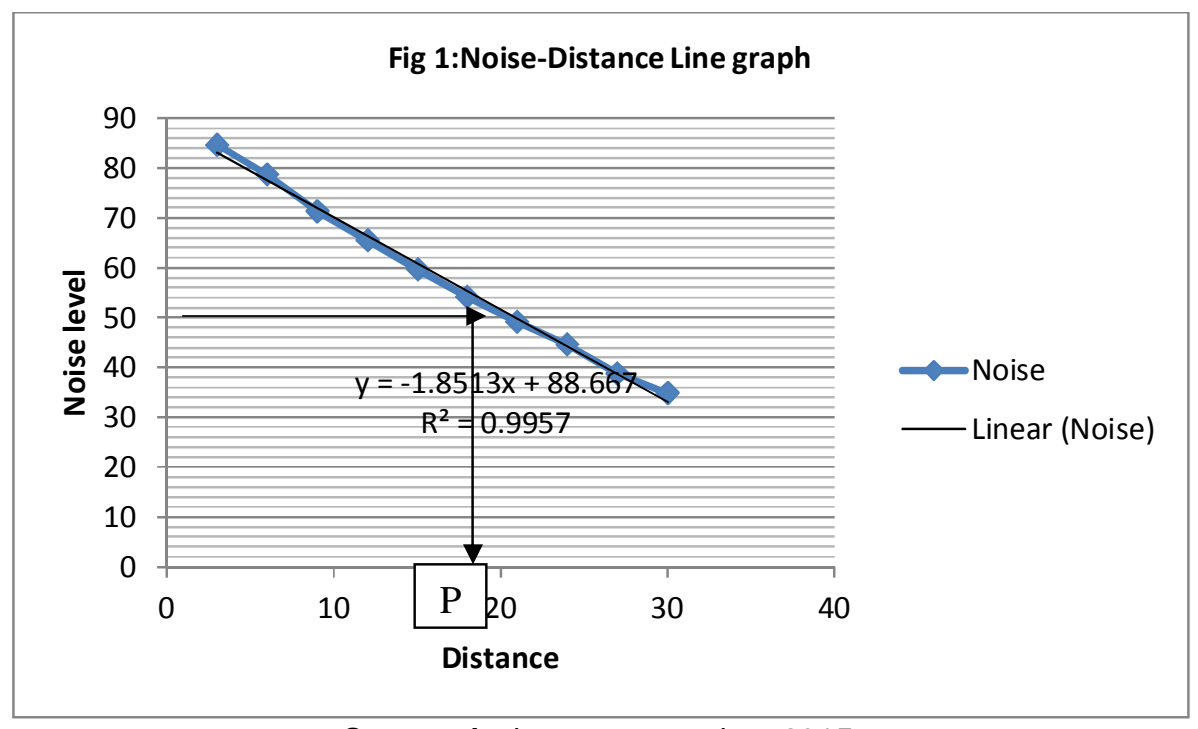

Source: Authors computation, 2015.

Noise was found to be a function of distance. It varies inversely with distance with a negative correlation of 0.851 . The coefficient of determination $\left(R^{2}=0.996\right)$ posits that there is a high degree of overlap between the two. In essence, putting the electric generator far away from where humans stay or sleep during its use would solve the problems causable by noise. Abatement method to alleviate the effects of generator use may look simple until we are confronted with the standard plot sizes and multiple plot arrangement. The maximum outdoor noise level that is safe according to WHO (1986) is $55 \mathrm{db}$. The average distance that would buffer the noise from most electric generators is $17.7 \mathrm{~m}$ (Point $\mathrm{P}$ on fig 1 ) which is almost midway within a standard high density plot and cannot be accommodated within the setback stipulated for any residential unit. In other words, an average high density standard plot would be too small to buffer a single electric generator effectively, if only distance is factored into the buffering. The situation becomes worse with multiple generators within a plot of such size. Again, all the adjoining plots that houses residential units may have similar situations. This ultimately increases the density of electric generators within a relatively small area.

The implication of this can be much. Individual efforts alone may not be sufficient to buffer away both the noise and fumes originating from multiple electric generators coming from all directions within the neighborhood. Understanding of the wind movement and cohesive collaboration of the neighborhood residents in partnership with governmental solution can go a longer way to mitigate the problems of noise and fumes.

\section{Distance Decay of Pollutants and the Environmental Carrying Capacity.}

Ambient air quality was taken at different points of varying distance from pollution source. It was observed that the concentration of the pollutant decreased with increase in distance away from the gaseous pollutant source. This may be because of diffusion. It follows that ample spaces within a plot would improve its carrying capacity. In essence, the bigger the plot, the possibility of reducing the local carbon load as far as the usage of electric power generators is concerned. 


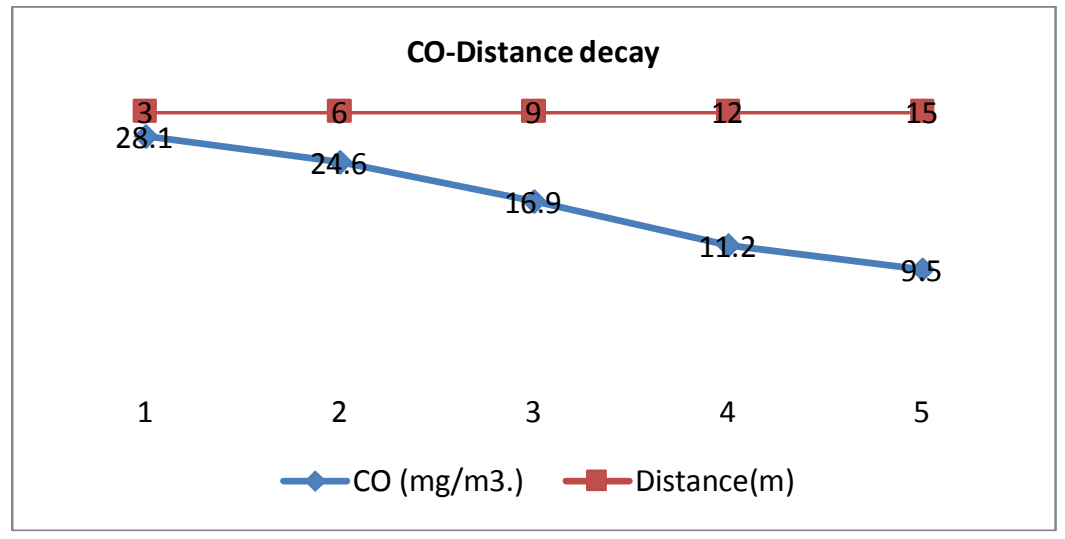

Figure 2: Carbon Monoxide Distance Decay

Source: Author's Field Survey, 2015.

It may be observed that keeping all other situations surrounding the incidence of fumes from generators constant; with each meter moved away from the pollution source, there is a $2.342 \mathrm{mg} / \mathrm{m}^{3}(8.3 \%)$ reduction in the CO concentration on the average. It follows that the desired domestic level of $\mathrm{CO}$ reduces in the study area by a constant of $2.342 \mathrm{mg} / \mathrm{m}^{3}$, which may be used to calculate the distance required at each instance for the placement of electric power generators in our homes

\section{Incidence of Greens and Air Quality}

Distance alone would not improve the local and global air quality. The presence of biological factors such as green plants which are believed to be contributing to environmental oxygen through photosynthetic activities can contribute immensely to the air quality. Ambient air quality in this study may be described as the degree of the absence of pollutants in the air. This was found to increase with increase in the incidence of green soft landscape materials in the area. Quadrant method was used to sample areas to measure the incidence of green plants in the area. Trees and shrubs were directly enumerated too. A weight of 4 was given to a quadrant (a quarter of quadrant scores 1); 5 was attached to shrubs while 7 was attached to a tree. The number of trees, shrubs and the incidence of green plant cover measured by the quadrant werecomputed and the summation was in interval scale. Air sampler was used to measure the ambient concentration of carbon monoxide across the sampled blocks the standard scores of these pollutants were plotted against the incidence of greenery.

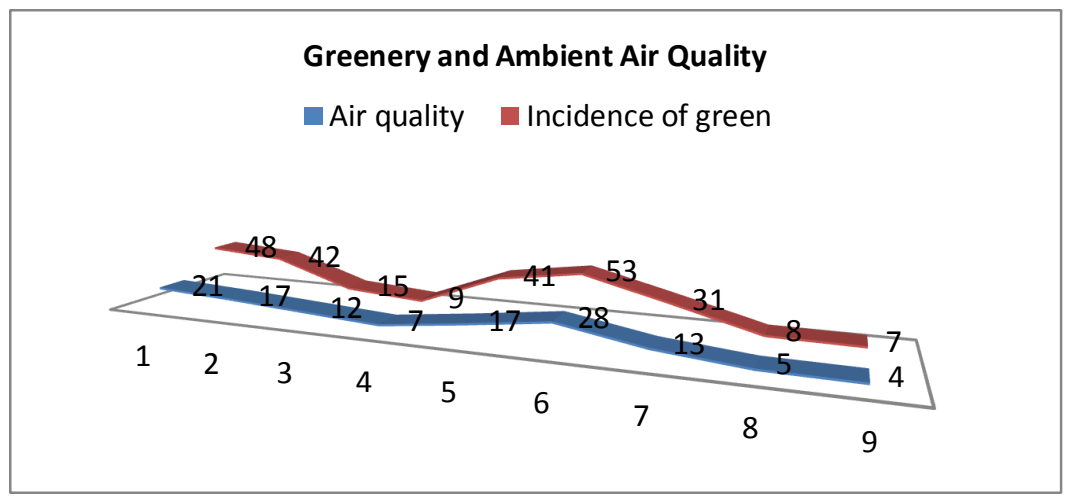

Figure 3: Greenery and Ambient Air Quality Source: Author's Field Survey, 2015.

It may be deduced from this study that incidence of greens is an efficient means to local carbon capture and sequestration. The higher the incidence of green landscape in the area, the better was the air quality observed and vice versa. From this study, a unit increase in the incidence of green landscape produces 1.916 corresponding increase in the ambient quality of the air. 


\section{CONCLUSIONS AND RECOMMENDATION}

The study has been able to investigate the usage incidence of electric power generator in Ogbomoso Nigeria. The incidence was found to be high at $78.6 \%$ among the residents. The negative externalities of the use of the same in terms of noise and effluence were also studied. For these externalities to be alleviated and for physical, health, social and psychological comfort of the residents, the study has been able to proffer a sustainable way of at least reducing the negative effects of electric power generators in residences. Hence, it is suggested here that residents are encouraged to house their generators and buffer its location with green plants such as the jathropacurcas that are capable of producing higher amount of oxygen during the dark reaction of photosynthesis (Olawale and Adeniyi, 2012). This would assist in the local carbon capture and sequestration. This effort can be complemented by the government through both the legislation and enforcement of standards as well as city greening in terms of tree planting, adequate road standard, creation of open spaces, parks and gardens which may increase the carrying capacity of the environment and deliver a better liveable environment.

\section{ACKNOWLEDGEMENT}

This is to acknowledge that this research was fully funded by the Senate Research Grant of the Ladoke Akintola University of Technology, Ogbomoso Oyo State, Nigeria. The participation of my students in the department of Urban and Regional Planning, LAUTECH during the data collection is also acknowledged and appreciated.

\section{REFERENCES}

Afolayan,Jide, TokunboOlajumoke, FrederickAmadasun\& Theodore Isesele (2014); Knowledge andAttitude of Nigerian personnel working at Federal Medical Centre in Nigeria on Carbon Monoxide Poisoning from ElectricalPower Generators, South African Family Practice, 56:3, 178-181, DOI: 10.1080/20786204.2014.936662 http://dx.doi.org/10.1080/20786204.2014.936662

Ajiboye B. O, Salawu S.O, OkezieB, Oyinloye B.E, Ojo A. O, Onikanmi S. A, Oso A.O, Asoso O.S and Obafemi T.O (2014); 'Mitigating Potential and Anti-Oxidant Properties of Leea-Guineensis Against Dichlorovosinduced Toxicity in Wistar Rats'. Journal of Toxicology and Environmental health Sciences Vol 6, No 7 pp132146

Berglund, B; Lindvall T, Schwela D, GohKT (1999): World Health Organization: Guidelines for Community Noise. World Health Organization.

Blumenthal I. (2001) Carbon Monoxide Poisoning Journal of Sociological Medicine 2001;94(6):270-272.

Burney RE, Wu SC, Nemiroff MJ. (1982) Mass Carbon Monoxide Poisoning: Clinical Effects and Results of Treatment in 184 Victims. Ann Emerg Med. 1982;11(8):394-399.11.

Centers for Disease Control and Prevention (2007). Unintentional Non-fire Related Carbon Monoxide Exposures in the United States. 1999-2004. MMWR Morb Mortal Wkly Rep. 2007;56(50):1309-1312.

Chambers, N., Simmons, C. and Wackernagel, M. (2000):Sharing Nature's Interest: Ecological Footprints as an Indicator of Sustainability. Earthscan, London ISBN 1-85383-739-3 (see also http://www.ecologicalfootprint.com)

Donney Albert (2011); 'Carbon Monoxide' http://coconundra.info/CO_levels.php

Fellmann Jerome D, Getis Author and Getis Judith (2010); Human Geography' Updated $6^{\text {th }}$ Edition. http://www.mhhee.com/Introduction-Geography-Author-Getie/dp/0073522880

Gasman JD, Varon J, Gardner JP (1990). Revenge of the barbecue grill.Carbon monoxide poisoning. West J Med. 1990;153(6):656-657.

Guy KM, Pimlott JK, Rogers M, Cross M. (1999);'The new CO and smoke inhalation advisory service in the UK Treatment of poisoning'. Indoor Built Environment. 1999;8:199-202

Heimbach DM, Waeckerie JF (1988). Inhalation Injuries.Ann Emergency Medicine.1988;17(12):1316-1320.

Ising H, Babisch W, Kruppa B (1999): Noise-Induced Endocrine Effects and Cardiovascular Risk. Noise Health1 (4): $37-48$.

Kirby Alex (2004,): Pollution: A life and death issue. BBC News. http://news.bbc.co.uk/1/hi/sci/tech/4086809.stm. Retrieved 2008-01-31.

Kryter, Karl D. (1994): The handbook of hearing and the effects of noise: physiology, psychology, and public health. Boston: Academic Press. ISBN 0-12-427455-2.

Lopez-Mirabal H.R, Thorsen M, Kielland-Brandt M.C, Toledano M.B, Winther J.R (2007); Cytoplasmic Glutathione Redox Status Determines Survival upon Exposure to the Thiol-Oxidant 4-4'dipyridyldisulphate. FEMS Yeast Res Volume 7 No 3, pp 391-403. www.yeastgenome.org/references/s0001204851/overview

McDonald EM, Shields W, Frattaroli S, et al. (2010) Carbon Monoxide Knowledge, Attitudes and Practices in Urban Households. Inj Prev. 2010;16(s1):A175.

Meredith TJ, Vale JA, Proudfoot A T (1987) Poison caused by inhalational agents. In: Weatherall DJ, Ledigham JGG, Warren D, editors. Oxford Text book of Medicine. $2^{\text {nd }}$ ed. Oxford: Oxford University Press; 1987;6:53-59 
Monfreda, C., M. Wackernagel and D. Deumling (2004): Establishing national natural capital accounts based on detailed Ecological Footprint and biological capacity assessments. Land Use Policy 21 (2004): 231-246.

Niemann, H. (2006): Noise-induced annoyance and morbidity results from the pan-European LARES study. Noise Health8 (31): 63-79. doi:10.4103/1463-1741.33537. PMID 17687182.

OlawaleUsmanDairo and AdeniyiTajudeenOlayanju (2012); Effects of Initial Catalyst Amount on Production of Bio-Diessel from 'jathropacurcas' Using In-Situ TechiqueTransnational Journal of Science and Technology Vol 2 No 6.

Oyedepo S. O. (2012) Energy and Sustainable Development in Nigeria: the Way Forward. Energy, Sustainability and Society. 2012;2:15.

Passchier-Vermeer, W. and W.F. Passchier (March 2000): Noise exposure and public health Environment Health Perspectives108 (1): 123-131. doi:10.2307/3454637. JSTOR 3454637.PMC 1637786.PMID 10698728.

Pichot, P. (1992): Noise, sleep and behavior. Bulletin de l'Academienationale de médecine176 (3): 393-9.

Saadu, A.A., R.O Onyeonwu, E.O. Ayorinde and F.O. Ogisi, 1998: Road Traffic Noise Survey and Analyses in some major urban centers in Nigeria Noise Control En. J,. 46:146-158

Schmidt, Charles W. (January 2005): Noise that Annoys: Regulating Unwanted Sound. Environmental Health Perspectives113 (1): A42-A44. doi:10.1289/ehp.113-a42

Seleye-Fubara D, Etebu EN, Athan B. (2011) Pathology of Deaths from Carbon Monoxide Poisoning in Portharcourt: an Autopsy Study of 75 cases. Niger J Med. 2011;20(3):337-340

Stansfeld S, Haines M, Brown B. (2000): Noise and health in the urban environment. Rev Environ Health. 2000 Jan-Jun;15(1-2):43-82.

Staples, Susan L. (Feb 1996):Human response to environmental noise: Psychological Research and public policy. American Psychologist51 (2): 143-150. doi:10.1037/0003-066X.51.2.143. PMID 8746149.

Talbott E, Helmkamp J, Matthews K, Kuller L, Cottington E, Redmond G.(1985): Occupational noise exposure, noise-induced hearing loss, and the epidemiology of high blood pressure. Am J Epidemiol.1985 Apr;121(4):501-514.

Touger M, Gallagher EJ, Tyrrel J (1995). Relationship between venous and arterial Carboxyhaemoglobin level in Patients with Suspected Carbon Monoxide Poisoning. Ann Emerg Med. 1995;25(4):481-483.

UN-Habitat (2011); 'Cities and Climate Change' Global Report on Human Settlements. NW Washington DC: Earthscan LLC USA

Wackernagel, Mathis and W. Rees.(1996): Our Ecological Footprint. Gabriola Island, BC: New Society Publishers, 1996.

Waldo R Tobler (1930); 'A Formulation of the Concept of Spatial Correlation' www.jstor.org/stable/3693985

Wakefield, Julie (2002): Learning the Hard Way. Environmental Health Perspectives110(6).

Westman JC, Walters JR.(1981): Noise and stress: a comprehensive approach. Environ Health Perspect. 1981 Oct:41:291-309.

The World Bank, (2004), http://www.worldbank.org/ United Nations Development Programme, 2004 http://www.undp.org/.

Walker T, Hay A. (1999) Carbon Monoxide Poisoning is still an under recognised Problem. BMJ. 1999;319(7212):1082-1083.

Cite this Article: Akindele OA and Adejumobi DO (2016). Mitigating the use of Electric Generators: An Operative Model of Distance and Greening Buffers. Greener Journal of Science Engineering and Technological Research, 6 (3): 070-077, http://doi.org/10.15580/GJSETR.2016.3.052416098 